\title{
Puheenvuoro
}

Ritva Leino

\section{Julkinen palvelu, huomiotalous ja datan valta Käyttäjäystävälliset datakäytännöt ovat valtava haaste}

Ritva Leino kirjoittaa Yleisradion ja Reilu Data -hankkeen yhteistyöstä vuosina 2018-2020. Hanke on osa Strategisen tutkimuksen neuvoston rahoittamaa Kansalaisuuden kuilut ja kuplat (BIBU) tutkimushanketta.

Yleisradion uusi strategia hyväksyttiin keväällä 2020. Sen keskeinen viesti on, että Yleisradio on kaikille yhteinen ja jokaiselle oma. Tämä kuvaa hyvin sitä haastetta, mikä julkisen palvelun mediayhtiöllä on aikana, jolloin median liiketoimintamalli on muuttunut ja verkko, sosiaalinen media ja suoratoistopalvelut toimivat toisin kuin perinteiset joukkotiedotusvälineet. Perinteinen media, sosiaalinen media ja suoratoisto tarvitsevat erilaiset tavat toimia.

Yleisradion on osattava tarjota kaikille relevanttia informaatiota, yhteisiä hetkiä ja olennaisia puheenaiheita. Sen on oltava kansakunnan kokoinen media. Tähän kykenevät parhaiten perinteiset joukkotiedotusvälineet. Mutta samaan aikaan median käyttötavat ja jakelukanavat ovat muuttuneet, kaikki suomalaiset eivät hakeudu tv-kanavien äärelle tai kuuntele radiota, vaan etsivät sisällön internetistä, applikaatioista, sosiaalisesta mediasta ja suoratoistopalveluista. Koska Ylen tehtävä on palvella kaikkia suomalaisia, sen on pystyttävä tarjoamaan sisältöä myös verkossa, silloin kun suomalaiset haluavat sitä siellä käyttää. Käytännössä tämä tarkoittaa, että Yleisradion on pystyttävä toimimaan kahdessa hyvin erilaisessa toimintamallissa hallittava sekä perinteinen joukkotiedotus että digitaalinen, verkottunut, dataan perustuva toimintatapa.

Tässä puheenvuorossa käsittelen sitä, miten median liiketoimintamalli on muuttunut, miten sisältöjen volyymit ovat kasvaneet ja aiheuttaneet löydettävyysongelman median käyttäjille, mutta myös mediataloille. Datasta on tullut keskeinen valuutta, sitä kerätään, sitä myydään, sen avulla kohdistetaan mainoksia, mutta myös sisältöjä ja se antaa mahdollisuuden valvoa ja käyttää valtaa. Valtavien datamäärien kerääminen ja hallinta on ollut mahdollista teknojäteille, mutta ei julkisen palvelun yhtiöille. Se on aiheuttanut mediamarkkinan vääristymän, mutta myös nostanut esiin kysymyksen teknoyhtiöiden vallasta ja turvallisten, käyttäjäystävällisten ja läpinäkyvien datakäytäntöjen rakentamisesta. Reilu Data -hankkeessa pohdimme ja kokeilimme millaiset asiat ja käytännöt voisivat edistää tätä. Mukana yhteistyössä oli Reilu data -hankkeesta Kaarina Nikunen ja Jenni Hokka sekä Yleisradiosta Raimo Lång ja allekirjoittanut, mutta myös Yle 
Opetuksen tekijöitä ja teimme yhteistyötä Yle Labin ja Yle News Labin välillä. Nämä viimeksi mainitut ovat Yleisradion tuotekehitysyksiköitä.

Tutkijat (Citton 2016; Wu 2016) ovat todenneet, että elämme huomiotaloudessa. Kun informaatiota ja sisältöjä on käytännössä äärettömästi, kilpailu käydään käyttäjän huomiosta. Sisältö on ilmaista, mutta tuote olemme me. Huomiotaloudessa median käyttäjällä on jatkuvasti vaikeuksia löytää itselleen kuhunkin tilanteeseen sopivaa sisältöä. Se, miten käyttäjät valitsevat sisällöt, perustuu heidän tarpeisiinsa, tunnetilaan, asenteisiin ja makuun (Webster ja Ksiazek 2012).

Lineaarinen joukkotiedotus, kuten televisio ja radio, perustuu ohjelmakarttoihin, toistoon. Se on suunnattu isoille yleisöille, jotka hakeutuvat itse kanavien pariin. Sen valuuttana on ollut katsojavolyymit ja tavoittavuus, jota mitataan Finnpanelin katsojamittauksessa. Vaikuttavuus mitataan sillä, miten onnistutaan tavoittamaan iso määrä ihmisiä.

Digitaalinen liiketoimintamalli perustuu dataan, sen keräämiseen ja hyödyntämiseen. Internetissä sisältöjä on äärettömästi ja löydettävyys on käyttäjän ongelma. Jotta mediasisältöjen tarjoajat - suoratoistopalvelut, sosiaalisen median palvelut - toimisivat tehokkaasti, niiden pitää kyetä "näkemään", mitä käyttäjät tekevät ja millaisia sisältöjä he haluavat. Siihen tarvitaan dataa, käyttäjien toiminnan jatkuvaa seuraamista. Data ja mittarit auttavat palvelun tarjoajia ymmärtämään koko ajan paremmin käyttäjien toimintaa, rakentamaan parempia suosittelualgoritmeja, kohdentamaan sisällöt paremmin käyttäjien tarpeiden ja käyttötottumuksen mukaan. Datan kerääminen liittyy paitsi sisällön parempaan suositteluun myös digitaalisen markkinoinnin kohdentamiseen juuri oikeille käyttäjille. Tästä käyttäjien datan keräämisestä ja sen jatkuvasta hyödyntämisestä on tullut digitaalisen median valuutta. Me käyttäjät tosin emme tiedä mitä dataa meistä kerätään, millaisia profiileja meistä rakennetaan ja mihin kaikkeen kerättyä dataa käytetään. Tämä on aiheuttanut huolta, pelkoa ja epäluottamusta käyttäjissä.

Juuri kukaan median käyttäjä ei enää toimi vain lineaarisessa maailmassa, vaan me kaikki käytämme ja kuljemme sujuvasti perinteisen ja digitaalisen maailman välillä. Nykyään nämä toimintamallit ovat vahvasti kietoutuneet toisiinsa. Jotta median käyttäjät löytäisivät sisällöt Areenasta, niitä on suositeltava sosiaalisessa mediassa. Yleisradion kaltaisella mediatoimijalla ei ole omia sosiaalisen median kanavia, joten se on riippuvainen globaalien teknologiayhtiöiden alustoista, kun se haluaa palvella kaikkia suomalaisia ja auttaa heitä löytämään itseään kiinnostavia sisältöjä. Juuri löydettävyys on verkossa julkaistujen sisältöjen suurin haaste. Toinen haaste liittyy luotettavan informaation julkaisemiseen sosiaalisen median palveluissa.

Palvellakseen paremmin Yleisradion kaltainen julkisen palvelun yhtiö ei myöskään pysty saamaan käyttöönsä teknologiayhtiöiden keräämää dataa. Se on niiden kultakanta, jota ne käyttävät oman liiketoimintansa edistämiseen. Tässä globaalit tekno alustat ja julkisen palvelun mediatoimijat ovat eri asemassa ja toimivat eri säännöin. Julkisen palvelun toimintaa säädellään ja valvotaan koko ajan, teknologiayhtiöiden toimintaa ei juuri ollenkaan. Lisäksi lainsäädäntö ei ole pysynyt teknologisen kehityksen vauhdissa.

Digitaalisen median toiminta edellyttää dataa, jotta mediatalo voisi suositella ja kertoa median käyttäjälle juuri häntä kiinnostavista sisällöistä ja olla jokaiselle suomalaiselle erilainen ja oma. Julkisen palvelun mediatoimija ei voi kerätä samalla tavalla dataa käyttäjistään. Jokainen kansainvälinen digitaalinen palvelu edellyttää rekisteröitymistä, oman tilin tekemistä. Jos median käyttäjä tekee Yle-tunnuksen, hän voi saada parempaa 
suosittelua ja tietoja itseään kiinnostavista uusista ohjelmista. Tämä on kuitenkin vapaaehtoista. Mitä vähemmän dataa Yleisradiolla on käytössä, sitä riippuvaisempi se on teknologiayhtiöiden alustoista suosittelussaan ja markkinoinnissaan. Kysymys on siitä, miten julkisen palvelun toimijan sallitaan keräävän dataa.

Toisaalta juuri julkinen palvelu voisi kehittää ja rakentaa vaihtoehtoisia, turvallisia ja läpinäkyviä datakäytäntöjä toisin kuin globaalit toimijat, joiden eettisistä periaatteista tai niiden puutteesta on käyty paljonkin keskustelua. BBC on siirtynyt vähitellen pakolliseen rekisteröintiin suoratoistopalvelussaan. Englannin kaupallinen julkisen palvelun yhtiö Channel 4 on jo vuosia edellyttänyt käyttäjiltään tunnuskirjautumista. Muutama vuosi sitten se myös lopetti YouTube-kanavan, johon se julkaisi lyhytmuotoista sisältöä, ja alkoi julkaista näitä vain omassa suoratoistopalvelussaan saadakseen kaiken datan itselleen.

Voidaan kysyä, kumpi on parempi, se että julkisen palvelun yhtiö on riippuvainen teknologiayhtiöiden alustoista vai se, että se kehittää ja rakentaa suomalaisten kannalta turvallisia datakäytäntöjä.

Amerikkalainen ja eurooppalainen mediaympäristö ovat poikenneet merkittävästi toisistaan. Euroopassa on ollut vahva julkisen palvelun media, kun Yhdysvalloissa media on ollut läpikotaisin kaupallinen. Amerikkalainen audiovisuaalinen teollisuus - etenkin Hollywood - on ollut alun alkaenkin kansainvälistä. Eurooppalainen media oli pitkään kansallista, vain rahoitus ja erilaiset yhteistuotantomallit olivat kansainvälisiä. Eurooppalaista mediaa on säädelty voimakkaasti, kun amerikkalainen media on avoimen kilpailun pelikenttä. Kun internet ja sen eri alustat ja palvelut rakentuivat, ne suunniteltiin kaikkialle, yhdistämään koko maailman ihmiset. Eurooppa ei pystynyt kilpailemaan kalifornialaisten teknologiayhtiöiden kanssa, vaan se on jäänyt riippuvaiseksi amerikkalaisesta teknologiayhtiöistä.

Kysymys on paitsi innovaatiokyvystä ja kilpailuasetelmasta myös yhteiskunnista ja arvoista. Hollantilaisen tutkijan Van Dijckin (Van Dijck ja Poell 2013) mukaan Silicon Valleyn arvot ja toimintalogiikka ovat nimenomaan kaupallisia ja hyvin ekspansiivisia. Teknologiayhtiöt ovat kuljettaneet amerikkalaiset arvot tuontitavarana osaksi eurooppalaista mediaekosysteemiä.

Van Dijck (emt.) toteaa, että eurooppalaisen median ja arvojen kohdatessa amerikkalaiset alustat syntyy arvojen epätasapaino. Elämme jatkuvassa jännitteisessä tilassa, jossa emme tiedä, mihin uskoa ja luottaa. Luottamuksen rapautuminen yhteiskunnassa on myrkkyä demokratialle niin kuin olemme viime aikoina saneet kokea. Julkisen palvelun median toimintaa ohjaavat julkisen palvelun arvot, kun sosiaalisen median toiminta on valjastettu alustojen voitontavoitteluun. Tämä vaikuttaa myös tekemisen käytäntöihin, kuten tässä numerossa "Vaakakupissa vaarat ja vastuu" -artikkelin kirjoittajat osoittavat. Sosiaalisen median alustat ovat muovanneet media-alan toimintaprosesseja ja julkisen palvelun tekijät tasapainoilevat jatkuvasti julkisen palvelun arvojen ja sosiaalisen median hyvin erilaisten käytäntöjen ristipaineessa.

Julkisella palvelulla on ollut erittäin tärkeä rooli eurooppalaisessa mediaekosysteemissä. Julkinen palvelu on taannut kaikille vapaan pääsyn länsimaisen demokratian kannalta keskeiseen informaatioon, luotettavasti. Columbian yliopiston digitaalisen journalismin vetäjä Emily Bell uskoo, että julkisen palvelun merkitys on nykyisessä mediaekosysteemissä nousemassa entistä tärkeämmäksi. Hän toteaa, että koska julkisen palvelun yhtiöiden rahoitus on melko turvattu, niiden pitäisi pystyä paremmin näkemään se, millaista mediaa ihmiset tässä ajassa tarvitsevat. (Hofseth 2018.) Olennaista on myös 
se, mitä päättäjät haluavat ja sallivat julkisen palvelun median olevan. Hän toteaa, että myös julkisen palvelun mediayhtiöiden pitää voida olla vapaita kuvittelemaan ja rakentamaan sellaisen mediajärjestelmän, jonka kansalaiset tarvitsevat. Hän uskoo, että tulevaisuuden media on enemmän globaalien teknojättien palveluiden kaltainen kuin perinteisen joukkotiedotuksen kaltainen systeemi. Bell näkee, että itse asiassa hyvä julkisen palvelun media on tärkeä, koska se nostaa koko alan standardeja. Eettiset kysymykset ovat nyt kaikkialla. Myös poliitikot ovat heränneet pohtimaan, millaista valtaa nämä teknoyhtiöt käyttävät ja mikä vaikutus sillä on demokratiaan.

Hyvin samanlaisista pohdinnoista ja kysymyksistä käynnistyi Reilu Data -hankkeen ja Yleisradion yhteistyö vuonna 2018. Hankkeessa Yleisradiosta oli aluksi mukana Yle Lab, joka on monimediainen tuotekehitysyksikkö, ja myöhemmin teimme aktiivisesti yhteistyötä Yle Oppimisen ja News Labin kanssa. Yhteistyö kesti kaksi vuotta, ja sen aikana tehtiin iso määrä verkkoartikkeleja, pelillisiä käyttäjiä aktivoivia projekteja sekä muita kokeiluja.

Tämä oli kiinnostava kokeileva yhteistyö, jossa halusimme myös käytännössä ymmärtää, mitä on datan valta ja miten se vaikuttaa julkisen palvelun toimintaan. Pohdimme yhdessä, miten käyttäjät sen kokevat sekä millaiset sisällöt ja kokeilut voisivat johdattaa meitä kohti kestävämpiä toimintamalleja. Aluksi jaoimme ajatuksia ja tutkimustietoa datasta, sen roolista sekä siitä, miksi ja miten olemme riippuvaisia globaaleista teknologia-alustoista ja mikä on niiden rooli osana julkisen palvelun mediaa. Vuonna 2019 keskityimme erilaisten sisältöjen sekä käyttäjätyöpajojen tekemiseen. Vakiintuneita tapoja oli kirjoittaa ja tuottaa erilaisia verkkoartikkeleja datan keruusta ja sen vaikutuksista ja siten kertoa siitä, millaista dataa meistä kerätään ja kuinka hyvin olemme perillä siitä mihin sitä käytetään.

Yle Oppiminen ja Uutisten PlusDeski tekivät useita aiheeseen liittyviä artikkeleja. Tämän lisäksi Yle Oppiminen teki verkkoon testejä, joilla käyttäjä saattoi selvittää, millaista dataa hänestä oli kerätty, ja ohjeita siitä, millaisilla toimilla voimme itse vaikuttaa omaan datajälkeemme. Näitä olivat projektit kuten Digitreenit: Mitä nettisivujen evästeet oikein tekevät, Digitreenit: Jätät aina verkkoon jälkiä - millä 9 keinolla karsit niitä, Millaisen jäljen sinä jätät verkkoon? Testaa oletko yksityisyydestäsi tarkka vai huoleton huitelija? Yhdessä jutussa kerrottiin myös se, mitä dataa Yle kerää ja miten se sitä käyttää. Yhtiö itse avasi dataprosessejaan. Areenaan tehtiin myös video, missä hakkeri Laura Kankaala vinkkasi, miten omia tietoja kannattaa suojata internetissä.

Datan keruusta ja sen vaikutuksista kertovaa materiaalia tehtiin monipuolisesti ja paljon. Yksi oletuksemme oli, että faktajournalismi ei välttämättä ole kovin tehokas tapa saada ihmisiä muuttamaan toimintaansa ja suojaamaan yksityisyyttään. Halusimme ymmärtää paremmin, miten ihmiset kokevat asian, kuinka huolissaan he ovat, ja ennen muuta mikä saisi heidät suojaamaan paremmin yksityisyyttään. Järjestimme käyttäjätyöpajoja, joissa testattiin käyttäjien kokemuksia datasta ja omien tietojensa keräämisestä sekä tiedusteltiin millaisia ajatuksia ja tunteita se heissä herätti. Useat haastateltavat kokivat datan keruun ahdistavana mutta totesivat samalla, ettei heillä ole aikaa ja tietoa toimia toisin. Jotkut kokivat asian niin haastavana etteivät halunneet miettiä asiaa sen enempää.

Saatoimme päätellä, että huolimatta siitä, että haastateltavat ja testihenkilöt olivat hyvin tietoisia dataistumisen laajuudesta ja kokivat olevansa datankeruun kohteita, he eivät tienneet mitä asialle voisi tehdä. Asia oli yksinkertaisesti liian haastava ja monimutkainen yksittäisen ihmisen ratkaista omassa arjessaan. 
Tavoitteenamme oli myös saada median edustajat ja toimittajat kiinnostumaan globaalien teknoalustojen toimintatavoista ja datan keruusta. Halusimme kutsua maailmanluokan puhujia sekä vaihtoehtoisten käytäntöjen kehittäjiä yhteen. Kaapelitehtaalla järjestettyyn LIFT-tapahtumaan syksyllä 2019 suunniteltiin dataan ja mediaan liittyvä kokonaisuus. Teemasta oli puhumassa kansainvälisesti arvostettu mediasosiologi Zeynep Tufekci ja tutkija Philip M. Napoli. Tufekci varoitti jo vuonna 2011 Twitterin kyvystä vahvistaa yhteiskunnallista liikehdintää. Vuonna 2013 hän kirjoitti siitä, että Facebook kykenee vahvistamaan rasismia, ja vuonna 2017 siitä, miten YouTuben algoritmin suositukset tukevat radikalisoitumista. Nämä liittyvät olennaisesti dataistumiseen ja teknojättien toiminnan eettisiin ongelmiin. Tapahtumassa oli myös paneelikeskustelu siitä, mitä julkisen palvelun media voisi olla datatalouden aikakaudella. Tätä pohtivat asiaa tutkineen Kaarina Nikusen ohella vaihtoehtoisia julkisen palvelun malleja tekevät kansainväliset toimijat. Heitä ovat BBC:n kehitysyksikön Bill Thompson, joka edusti yhtiön Public Service Internet -hanketta. Hollantilaisilla on oma koko julkisen palvelun mediaa ja kulttuurilaitoksia yhdistävä Public Spaces -hanke ja englantilaisilla julkisen palvelun eettistä tilaa rakentava Public Media Stack. Kaikki nämä puheenvuorot olivat nähtävissä Yle Areenassa.

Yhteistyön aikana tulimme tietoiseksi siitä, että tärkeämpää kuin puhua dataistumisesta ja tehdä sitä näkyväksi, on yrittää muuttaa käytäntöjä ja kehittää uusia kestävämpiä datamalleja. Tässä julkisen palvelun toimijoilla olisi tärkeä yhteistyön paikka. Esittelimme Ylen sisällä asiaa Ylen vastaaville päätoimittajille. Sen lisäksi perustimme muutoshankkeen nimeltä Innovation Challenge, jonka tavoitteena oli haastaa kotimaiset ja eurooppalaiset startup-yritykset kehittämään terveitä ja kestäviä datakäytäntöjä julkisen palvelun medialle. Haasteen ja siihen liittyvän pitchausprosessin veti Avanto. Haaste oli niin kova, ettei yksikään startup-yritys pystynyt annetussa ajassa (kuukausi) vastamaan haasteeseen niin, että olisimme saaneet edes yhden relevantin ehdotuksen.

Yhteistyö Reilu data -projektin kanssa opetti meille monta asiaa. Se vahvisti oletuksemme siitä, että journalismi on hyvä tapa saada ihmiset tiedostamaan paremmin dataan liittyviä kysymyksiä ja herättämään ainakin joitakin kansalaisia tarkemmiksi omien palveluasetustensa kanssa. Journalismi ja tiedottaminen eivät kuitenkaan saa ihmisiä muuttamaan käyttäytymistään ja toimimaan toisin, vaan ne jopa lisäävät ahdistusta. Kun asiasta kerrotaan, samaan aikaan pitäisi pystyä tarjoamaan hyvin käytännöllisiä parannusehdotuksia ihmisten arkeen.

Käyttäjätyöpajat auttoivat meitä myös ymmärtämään, miten vaikea ja haastava asia datan keruu ja dataistuminen ihmisille on. Yksityisen ihmisen on vaikea ratkaista ongelmaa oman tietoturvansa ja oman mediankäyttönsä puitteissa. Kolmas asia, jonka opimme käynnistämästämme datahaasteesta, on ehkä kaikkein suurin. Julkisen palvelun halu rakentaa vaihtoehtoisia, terveempiä datakäytäntöjä on valtava haaste, johon vastaaminen on pienille teknoyrityksille mahdoton. Siihen tarvitaan yhteistyötä ja julkisesta palvelusta vastaavien päättäjien vaikutusvaltaa. Kysymys on siitä, miten poliittiset päättäjät ja julkisen palvelun johtajat näkevät kysymyksen tässä ajassa. Se vaatii Euroopan yleisradiounionin (EBU) tukea ja Euroopan laajuista yhteistä kehityshanketta, poliittista ymmärrystä ja tahtotilaa, julkisen palvelun toimijoiden yhteistyötä ja ison määrän resursseja. 


\section{Kirjallisuus}

Citton, Yves. 2016. The Ecology of Attention. Cambridge: Polity Press.

Hofseth, Anders. 2018. Emily Bell thinks public service media today has its most important role to play since World War II, NiemanLab 2.4.2018. Luettu 10.6.2021. https://www.niemanlab.org/2018/04/emily-bell-thinks-public-service-media-today-has-its-most-importantrole-to-play-since-world-war-ii/.

Van Dijck, José ja Thomas Poell. 2013. "Understandig Social Media Logic." Media and Communication 1 (1): 2-14. https://doi.org/10.17645/mac.v1i1.70.

Wu, Tim. 2016. The Attention Merchants. New York: Alfred A. Knopf.

Webster, James G. ja Thomas B. Ksizek. 2012. "The Dynamics of Audience

Fragmentation: Public Attention in an Age of Digital Media." Journal of Communication 62: 3956. https://doi.org/10.1111/j.1460-2466.2011.01616.x. 